\title{
An Investigation of Justice in Supply Chain Trust and Relationship Commitment - An Empirical Study of Pakistan
}

\author{
- Ziaullah Mubammad, Feng Yi, Akbter Shumaila Naz, Ahmad Saleem
}

\begin{abstract}
In recent years supply chain integration (SCI) has received increasing attention from scholars and practitioners. However, our knowledge of what influences the supply chain integration practice of relationship commitment is still very limited. The objective of this study is to investigate the relationship among supply chain justices (procedural, distributive and interactional), trust and inter-firms relationship commitment in mainland Pakistan. The research variables have considerable importance in the literature of supply chain management (SCM). The conceptual model comprises five hypotheses. Then hypotheses are tested via an empirical study in which data are collected from 170 manufacturers, distributors, suppliers and retailers of main stream spectrum industries in Pakistan. We used exploratory factor analysis (EFA), confirmatory factor analysis (CFA) to examine the validity and reliability of the measurement model, and structural equation modeling (SEM) to test the hypotheses. The findings delineate that supply chain justices can develop relationship commitment (affective and continuance) via establishing trust among supply chain partners. Moreover, this study reveals interesting and useful implications of supply chain justices, trust and relationship commitment for practitioners.
\end{abstract}

Keywords: supply chain justices, trust, relationship commitment, Pakistan

JEL Classification: L14

\section{INTRODUCTION}

Supply chain integration (SCI) research has gained much attention and interest due to the changing manufacturing strategies and dramatic increase in globalization (Cousins \& Menguc, 2006). Relationship commitment is the most famous practice of supply chain integration in supply chain management literature (Zhao et al., 2008; Flynn et al., 2008).

Relationship commitment is an attitude of Supply chain partners about the development and maintenance of a stable, long lasting mutual relationship (Anderson \& Weitz, 1992; Moore, 1998). It is the willingness to invest, financial, physical and relationship based resources in relationship (Moorman, 1992; Morgan \& Hunt, 1994). Moreover, Allen \& Meyer (1990) have characterized commitment as an affective and continuance. The affective commitment is based on the "affective or emotional attachment to the organization such that the strongly committed individual identifies with, is involved in, and enjoys membership in the organization. The continuance commitment in exchange relationship is built on the side bets, switching costs and scarcity of alternatives. 
It is investigated that successful alliances have a long term orientation that required loyalty, trust, sharing of risk and reward and information (Ellram \& Cooper, 1990). In the logistics alliances parties of the relationships seek to benefit from synergy of working together (Bowersox, 1990). Supply chain partners can develop trust by sharing benefits and burdens, so in this way relationship parties are able to manage their risk. Subsequently, these relationships are characterized by a high level of trust, dependency, cooperation, sharing of risk and rewards (Moore, 1998). Based on the aforementioned researches, we deduce that trust and commitment play significant role in the supply chain integration. Therefore, we are interested to verify and understand the supply chain justices (procedural, distributive and interactional) consequences in the Pakistan firms supply chain. The key research questions this study tries to address are as follows:

1. How justice can develop trust in the supply chain of Pakistan firms?

2. Does trust contribute to establish strong relationship commitment in the Pakistan firms supply chain?

The remainder of this paper is structured as follows. Section 2, a brief literature review of supply chain justices, trust, relationship commitment, and a set of four hypotheses related to the conceptual model are presented. Section 3, the research methodology is described. Section 4, data analysis and discussion of results are given. Managerial implications, conclusions, limitations and future research direction are illustrated in Section 5.

\section{LITERATURE REVIEWS AND RESEARCH HYPOTHESES}

This study investigates the effects of supply chain justices on trust and the consequent impact on relationship commitment. A review of detailed related literature was undertaken with the main focus on defining the research variables as well as the conceptualized relationship between them. The research framework is presented in Fig.1.

Supply Chain justice $\quad>\quad$ Supply Chain Trust $>$ Relationship Commitent

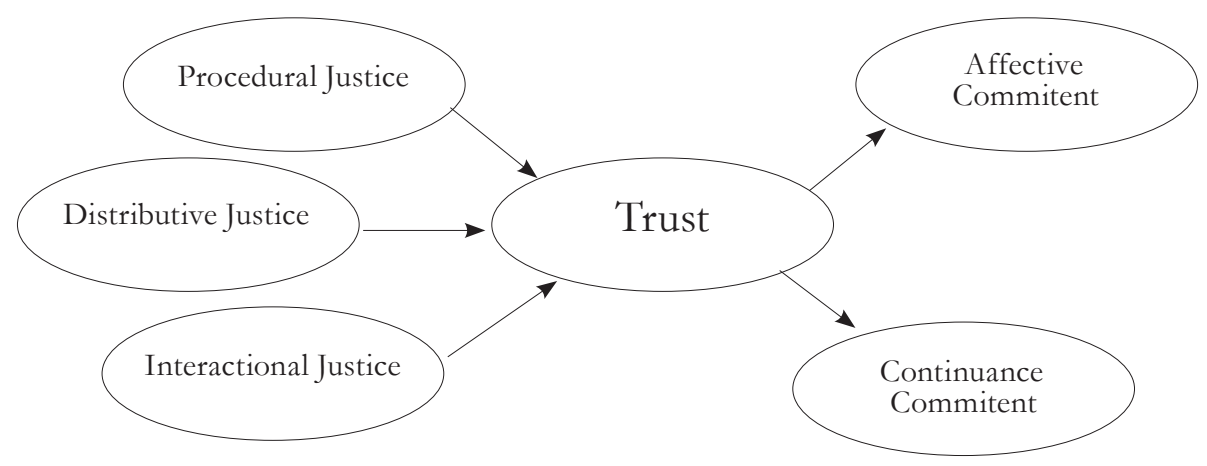

Fig.1. - Research Framework 


\subsection{The relationship between supply chain procedural justice and trust}

The first dimension is supply chain procedural justice (PJ). It refers as fairness about the policies and procedure to be used to handling the vulnerabilities between the partners. It refers that fairness regarding means which have been used to determine the outcomes in the relationship. Procedural justice has the stronger effects on the relationship as compared to the distributive justice, weaker partner has examined and evaluate the strong partner system of PJ which stimulate and strengthen the relationship intensity (Kumar, 1996).

Faire procedures and processes have been found that moderate the impact of negative reactions such as mistrust. The various dynamics of procedural justice have linked to a number of positive attitudinal and behavioral reactions as improved trust in management (Tyler \& Lind, 1992). PJ has a positive influence on the manager's belief to encourage the employee initiatives and to share information with them (Wang \& Nayir, 2009). Particularly, recognizing the importance of Integrity ensures the fair and consistent application of moral and ethical procedure to generate equity and trust (Bews \& Uys, 2002). However, the lack of procedural justice has likely to generate lower levels of trust. These kinds of perceptions have more impact as compared to distributive justice because the outcomes have been viewed to happening only once while procedures are consistent and considered to have a more enduring quality (Pillai et al., 2001). Therefore, we propose the following hypothesis.

H1: There is a positive relationship between supply chain procedural justice and trust in the context of supply chain relationships of firms in Pakistan.

\subsection{The relationship between supply chain distributive justice and trust}

Distributive justice is the second dimension, and Adams (1965) defines distributive justice as equity; likewise ratios of outcomes to inputs are equal to the ratio of outcomes to inputs of others. It refers as the equity of reward commensurate as efforts expanded in the relationship shared between the partners (Kumar, 1996). It argues that higher level of organizational outcome distribution will likely ensure the highest level of trust (Pillai et al., 2001), the manifestation of trust is based on the fulfillment of the obligations (Herriot et al.,1998) and fulfillment of obligations is positively related with generation of trust (Saunders \& Thornhill, 2003). Therefore, we propose the following hypothesis.

H2: There is a positive relationship between supply chain distributive justice and trust in the context of supply chain relationships of firms in Pakistan.

\subsection{The relationship between supply chain interactional justice and trust}

The third dimension is interactional justice, which deals the aspect of the communication processes and the degree to which partners perceives the exchange of information as fair in the relationship. It is the way to acquire the appropriate insights about the individual who are conducting the business and the organizations themselves (Narasimhan et al., 2013). It is the only justice dimension that is the best predictor of organizational performance (Wang et al., 2010). Moreover, interactional justice comprising two forms, namely interpersonal and informational justice. Interpersonal justice refers as individual reactions about the decision outcome while 
information justice refers as individual reactions about the procedures (Greenberg, 1990; Greenberg \& Greenberg, 1993). Interactional justice in which people have been treated has likely to generate the significant impact on the perceptions not only about the process, but also the moral obligations to treat everyone fairly, that reinforces the process and their levels of trust (Saunders $\&$ Thornhill, 2003). Therefore, we propose the following hypothesis.

H3: There is a positive relationship between supply chain interactional justice and trust in the context of supply chain relationships of firms in Pakistan.

\subsection{The relationship between supply chain trust and relationship commitment}

Trust is a willingness to rely on the exchange partner (Moorman et al., 1993). Trust has gained significant importance and to become one of the top priorities of upholding the relationship among the supply chain partners (Yeung et al., 2009). The high level of trust relationship produces vital benefits for supply chain partners as it improves firm performance and increase the relationship satisfaction (Johnston et al., 2004). Relationship commitment has been identified, one the critical factor that discriminate whether relationship to be continued or break down (Wilson \& Vlosky, 1998).

Allen and Meyer (1990) have characterized commitment as an affective and continuance. The affective commitment is based on the "affective or emotional attachment to the organization such that the strongly committed individual identifies with, is involved in, and enjoys membership in the organization. The continuance commitment in exchange relationship is built on the side bets, switching costs and scarcity of alternatives.

Particularly trust increases the confidence of the partners and improves commitment that reduces risk of opportunistic behavior in the effectiveness of the future exchange relationship and enforced to commit to the relationship (Moore, 1998; De Ruyter et al., 2001). Therefore, we propose the following hypotheses.

H4: There is a positive relationship between supply chain trust affective commitments in the context of supply chain relationships of firms in Pakistan.

H5: There is a positive relationship between supply chain trust and continuance commitment in the context of supply chain relationships of firms in Pakistan.

\section{RESEARCH METHODOLOGY}

\subsection{Questionnaire design}

The questionnaire included questions about the demographic profile of the companies, and questions related to the supply chain justices, trust and processes integration. Therefore, we surveyed the literature to identify valid measures for related constructs and adapted existing scales to measure supply chain justices i.e. procedural and distributive (Narasimhan et al., 2013; Griffith et al., 2006), interactional (Narasimhan et al., 2013; Luo, 2007), trust (Kumar et al., 1995; Chen et al., 2011) and relationship commitment (Allen \& Meyer, 1990; Wu et al., 2004). Since the drawn scales from literature were in English. Thus, we used the English version questionnaire with minor modifications in mainland Pakistan, because the official language is English 
in Pakistan. All the items were measured on a seven-point-Likert scale ranging from strongly disagree to strongly agree (1=strongly disagree; $7=$ strongly agree). The complete scales are listed in Appendix A.

\subsection{Sampling and data collection}

The data used to test the hypotheses are drawn from the diverse spectrum of industries in Pakistan. The study sample units were consisted of a wide range of industries including electronics and communication, mechanical manufacturing (tractors), cement, foods, textile, agriculture (fertilizers and pesticide), petroleum, furniture, retail and tobacco. The companies taking part in the survey have regional, national and international operational domains. The survey was conducted from June to August 2014. The study respondents belong to the medium and large sized companies which are residing in major cities (i.e. Karachi, Sukkur, Dera Ghazi Khan, Multan, Sahiwal \& Lahore) of Pakistan.

The survey provides the respondents an incentive for completing and returning the questionnaires. Therefore, two hundred fifty questionnaires were distributed initially, a total of 197 questionnaires were returned. Out of the 197 collected, 27 questionnaires were either incomplete or answers were found to be unreliable. Subsequent data analyses were conducted on the 170 usable questionnaires. The response rate was $78.80 \%$. The profile of the useable respondents and their characteristics are listed in Table 1.

Tab.1 - Respondent profile ( $\mathrm{n}=170)$. Source: Authors Own

\begin{tabular}{|l|l|c|c|}
\hline \multirow{5}{*}{ Demographics Variable } & Category & Sample & Ratio \\
\hline \multirow{5}{*}{ Job Title } & General Manager & 8 & $4.7 \%$ \\
& Production Manager & 17 & $10.0 \%$ \\
& Sales/Marketing Manager & 42 & $24.7 \%$ \\
& Admin. Manager & 33 & $19.4 \%$ \\
& Financial Manager & 36 & $21.2 \%$ \\
& Sales Executive & 28 & $16.5 \%$ \\
& Not reported & 6 & $3.5 \%$ \\
\hline \multirow{5}{*}{ Experience } & 1-3 Year & 45 & $26.5 \%$ \\
& 4-6 Year & 40 & $25.3 \%$ \\
& 7-12 Year & 42 & $24.7 \%$ \\
\hline \multirow{5}{*}{ Nature of Ownership } & More than 12 Year & 18 & $10.6 \%$ \\
& Sate Owned & 1 & $88.8 \%$ \\
& Private & $0.6 \%$ \\
\hline
\end{tabular}




\begin{tabular}{|c|c|c|c|}
\hline \multirow{10}{*}{ Industry } & Electronic \& Communication & 25 & $14.7 \%$ \\
\hline & Mechanical Mfg./Tractors & 17 & $10.0 \%$ \\
\hline & Cement & 12 & $7.1 \%$ \\
\hline & Foods & 21 & $12.4 \%$ \\
\hline & Textile & 11 & $6.5 \%$ \\
\hline & Fertilizer/Pesticides & 25 & $14.7 \%$ \\
\hline & Furniture \& Fixture & 15 & $8.8 \%$ \\
\hline & Retail & 16 & $9.4 \%$ \\
\hline & Tobacco & 11 & $6.5 \%$ \\
\hline & Petroleum / Refinery & 17 & $10.0 \%$ \\
\hline \multirow{6}{*}{ No. of employees } & $<200$ & 80 & $47.1 \%$ \\
\hline & $200-500$ & 9 & $5.3 \%$ \\
\hline & $500-1000$ & 22 & $12.9 \%$ \\
\hline & $1000-3000$ & 12 & $7.1 \%$ \\
\hline & $3000-5000$ & 13 & $7.6 \%$ \\
\hline & $>5000$ & 34 & $20.0 \%$ \\
\hline \multirow{6}{*}{ Firm's sales (Pak rupees) } & $<10$ & 9 & $5.3 \%$ \\
\hline & $10-100$ & 25 & $14.7 \%$ \\
\hline & $100-300$ & 41 & $24.1 \%$ \\
\hline & $300-1000$ & 10 & $5.9 \%$ \\
\hline & $1000-3000$ & 8 & $4.7 \%$ \\
\hline & $>3000$ & 77 & $45.3 \%$ \\
\hline \multirow{4}{*}{ Nature of firms } & Manufacturer & 84 & $49.4 \%$ \\
\hline & Wholesaler/Distributor & 49 & $28.8 \%$ \\
\hline & Retailer & 17 & $10.0 \%$ \\
\hline & Supplier & 20 & $11.8 \%$ \\
\hline \multirow{3}{*}{ Operational Area } & Regional & 73 & $42.9 \%$ \\
\hline & National & 66 & $38.8 \%$ \\
\hline & International & 31 & $18.2^{\%} \%$ \\
\hline
\end{tabular}

\subsection{Construct development}

Kaiser-Meyer-Olkin (KMO) applied to measure sampling adequacy and the Bartlett test of sphericity. The output shows KMO value of 0.935 with the significance of Bartlett's test at 0.000 level, and also indicates the data for exploratory factor analysis (EFA) fitting. We used maximum likelihood analysis for data reduction and promax rotation with Kaiser Normalizations for clarifying the factors. Hence EFA was conducted with specifying six numbers of factors. The 
cumulative variance explanation reaches $75.61 \%$. All the items have strong loadings $>0.30$ on the construct in the pattern matrix. Hair et al. (1998) supported this value. The results of EFA are shown in Table 2.

Tab.2 - Results of exploratory factor analysis (EFA). Source: Authors Own

\begin{tabular}{|c|c|c|c|c|c|c|}
\hline $\begin{array}{l}\text { Construct } \\
\text { items }\end{array}$ & $\begin{array}{l}\text { Affective } \\
\text { commit- } \\
\text { ment }\end{array}$ & $\begin{array}{l}\text { Continu- } \\
\text { ance com- } \\
\text { mitment }\end{array}$ & Trust & $\begin{array}{c}\text { Procedural } \\
\text { justice }\end{array}$ & $\begin{array}{l}\text { Distribu- } \\
\text { tive justice }\end{array}$ & $\begin{array}{c}\text { Inter- } \\
\text { actional } \\
\text { justice }\end{array}$ \\
\hline AFC1 & 0.989 & & & & & \\
\hline $\mathrm{AFC} 2$ & 0.936 & & & & & \\
\hline AFC3 & 0.817 & & & & & \\
\hline AFC4 & 0.634 & & & & & \\
\hline AFC5 & 0.523 & & & & & \\
\hline CC1 & & 0.876 & & & & \\
\hline CC2 & & 0.784 & & & & \\
\hline CC3 & & 0.860 & & & & \\
\hline CC4 & & 0.539 & & & & \\
\hline TST1 & & & 0.923 & & & \\
\hline TST2 & & & 0.919 & & & \\
\hline TST3 & & & 0.814 & & & \\
\hline TST4 & & & 0.789 & & & \\
\hline TST5 & & & 0.683 & & & \\
\hline TST6 & & & 0.518 & & & \\
\hline PJ1 & & & & 0.750 & & \\
\hline PJ2 & & & & 0.655 & & \\
\hline PJ3 & & & & 0.562 & & \\
\hline DJ1 & & & & & 0.774 & \\
\hline DJ2 & & & & & 0.771 & \\
\hline DJ3 & & & & & 0.608 & \\
\hline DJ4 & & & & & 0.589 & \\
\hline IJ1 & & & & & & 0.687 \\
\hline IJ2 & & & & & & 0.652 \\
\hline IJ3 & & & & & & 0.513 \\
\hline
\end{tabular}

Extraction Method: Maximum Likelihood. Rotation Method: Promax with Kaiser Normalization. a. Rotation converged in 7 iterations. * PJ: procedural justice, DJ: distributive justice, IJ: interactional justice PI: processes integration, TST: trust, AFC: Affective commitment, CC: Continuance commitment 


\section{Reliability analysis}

We used Cronbach's alpha to evaluate the construct reliability (Flynn et al., 1990), with threshold value of 0.70 recommended by Hair et al. (2006). In our study all the constructs are higher than the minimum recommended critical value. As shown in Table 3, Cronbach's alpha values of the measures are above the minimum recommended critical value and ranged from 0.88 to 0.95 . Therefore, results demonstrate the highly reliable theoretical constructs of the study.

\section{Unidimensionality}

Confirmatory factor analysis (CFA) is used to establish unidimensionality. The CFA results of all measurement models have acceptable fit indices that prove unidimensionality of the constructs which can be seen from Table 4. Furthermore, the convergent and discriminant validities established in the subsequent section to solidify the extent of unidimensionality of the constructs.

\section{Convergent and discriminant validity}

Standardized factor loadings of all items in each construct range from i.e. supply chain procedural justice (0.945-0.735), distributive justice (0.936-0.889), interactional justice (0.945-0.881), trust (0.929-0.665), affective commitment (0.947-0.665) and continuance commitment (0.9330.804), that exceed the minimum recommended level of 0.60 (Hair et al.,1998). The composite reliabilities (CR) range from 0.95 (distributive justice) to 0.86 (procedural justice) which also exceed the minimum required recommended level of 0.70 . The average variance extracted (AVE) measure ranges from 0.84 (interactional justice) to 0.66 (trust) which is better than the threshold value of 0.50 (Hair et al., 1998).

The average variance extracted (AVE) of each construct is greater than the variance shared with other constructs that can be seen in Table 3. That exhibited the discriminant validity of all scales is adequate. Moreover, all AVE exceeded 0.50, which indicates strong construct validity. In overall the measurement results are satisfactory and recommended that it is appropriate to proceed with the investigation and evaluation of the theoretical constructs. Moreover, the higher value of AVE, CR and factor loading results show the adequate convergent validity of the measurement items. The results of the convergent validity test are also presented in Table 3.

Tab.3 - Results of internal reliability and convergent validity tests. Source: Authors Own

\begin{tabular}{|l|l|c|c|c|c|c|}
\hline \multicolumn{2}{|l|}{$\begin{array}{l}\text { Construct } \\
\text { Items }\end{array}$} & Cronbach $\alpha$ & $\begin{array}{c}\text { Item Total } \\
\text { Correlation }\end{array}$ & $\begin{array}{c}\text { Standardized } \\
\text { Factor Loadings }\end{array}$ & $\begin{array}{c}\text { Composite } \\
\text { Reliability }\end{array}$ & $\begin{array}{c}\text { Variance } \\
\text { Extracted }\end{array}$ \\
\hline \multirow{5}{*}{ AFC } & AFC1 & & 0.793 & 0.947 & & \\
& AFC2 & & 0.886 & 0.913 & 0.92 & 0.70 \\
& AFC3 & 0.91 & 0.576 & 0.857 & & \\
& AFC4 & & 0.869 & 0.765 & & \\
\hline
\end{tabular}




\begin{tabular}{|c|c|c|c|c|c|c|}
\hline CC & $\begin{array}{l}\text { CC1 } \\
\text { CC2 } \\
\text { CC3 } \\
\text { CC4 }\end{array}$ & 0.88 & $\begin{array}{l}0.728 \\
0.666 \\
0.836 \\
0.741\end{array}$ & $\begin{array}{l}0.804 \\
0.933 \\
0.854 \\
0.839\end{array}$ & 0.92 & 0.74 \\
\hline TST & $\begin{array}{l}\text { TST1 } \\
\text { TST2 } \\
\text { TST3 } \\
\text { TST4 } \\
\text { TST5 } \\
\text { TST6 }\end{array}$ & 0.92 & $\begin{array}{l}0.559 \\
0.761 \\
0.832 \\
0.871 \\
0.825 \\
0.729\end{array}$ & $\begin{array}{l}0.929 \\
0.836 \\
0.717 \\
0.892 \\
0.804 \\
0.665\end{array}$ & 0.92 & 0.66 \\
\hline PJ & $\begin{array}{l}\text { PJ1 } \\
\text { PJ2 } \\
\text { PJ3 }\end{array}$ & 0.90 & $\begin{array}{l}0.801 \\
0.834 \\
0.766\end{array}$ & $\begin{array}{l}0.945 \\
0.781 \\
0.735\end{array}$ & 0.86 & 0.68 \\
\hline DJ & $\begin{array}{l}\text { DJ1 } \\
\text { DJ2 } \\
\text { DJ3 } \\
\text { DJ4 }\end{array}$ & 0.95 & $\begin{array}{l}0.877 \\
0.904 \\
0.886 \\
0.879\end{array}$ & $\begin{array}{l}0.889 \\
0.891 \\
0.936 \\
0.920\end{array}$ & 0.95 & 0.83 \\
\hline IJ & $\begin{array}{l}\text { IJ1 } \\
\text { IJ2 } \\
\text { IJ3 }\end{array}$ & 0.94 & $\begin{array}{l}0.842 \\
0.909 \\
0.882\end{array}$ & $\begin{array}{l}0.917 \\
0.945 \\
0.881\end{array}$ & 0.94 & 0.84 \\
\hline
\end{tabular}

\section{DATA ANALYSIS AND DISCUSSION OF RESULTS}

We used AMOS to analyze the data and demonstrate structural equation modeling (SEM), which is a powerful multivariate analysis technique used to measure latent variables and investigate the causal relationship among variables. Particularly, SEM allows conducting confirmatory factor analysis (CFA) for theory development and testing. It is helpful and deemed a suitable tool to test the hypotheses in this study. The overall model fit indices are $\mathrm{x}^{2}=500.82, \mathrm{df}=251$ ( $\mathrm{p}$-values=0.00), GFI=0.91, AGFI=0.91, NFI=0.91, CFI=0.95, RMSEA=0.048 indicating that model is acceptable with no substantive differences. The fit indices of structural model are presented in Table 4. Moreover the description of the model factor correlation matrix is given in Table 5. 
Tab.4 - Fit indices for structural model. Source: Authors Own

\begin{tabular}{|c|c|c|}
\hline Fit Index & Scores & $\begin{array}{l}\text { Recommended } \\
\text { cut-off values }\end{array}$ \\
\hline \multicolumn{3}{|l|}{ Absolute fit Measures } \\
\hline Minimum fit function chi-square $\left(\mathrm{x}^{2}\right)$ & $500.82(\mathrm{p}=0.00)$ & The lower, the better \\
\hline Degree of freedom (d.f) & 251 & \\
\hline$\left(x^{2}\right) /$ d.f & 1.99 & $<5$ \\
\hline Goodness-of-fit index (GFI) & 0.91 & $>0.80$ \\
\hline Root mean square residual (RMSR) & 0.048 & $<0.05$ \\
\hline \multicolumn{3}{|l|}{ Incremental fit measures } \\
\hline Adjusted goodness-of-fit index (AGFI) & 0.91 & $>0.80$ \\
\hline Tucker-Lewis index (TLI) & 0.94 & $>0.90$ \\
\hline Normal fit index (NFI) & 0.91 & $>0.90$ \\
\hline Comparative fit index (CFI) & 0.95 & $>0.90$ \\
\hline \multicolumn{3}{|l|}{ Parsimonious fit measures } \\
\hline Parsimonious normed fit index (PNFI) & 0.76 & The higher, the better \\
\hline Parsimonious goodness-of-fit index (PGFI) & 0.63 & The higher, the better \\
\hline
\end{tabular}

Tab. 5 - Mean, standard deviation and correlation matrix. Source: Authors Own

\begin{tabular}{|c|c|c|c|c|c|c|c|c|}
\hline Factor & Mean & SD & DJ & AFC & TST & CC & PJ & IJ \\
\hline DJ & 4.9618 & 1.4623 & 1.000 & & & & & \\
\hline AFC & 4.5365 & 1.2108 & 0.606 & 1.000 & & & & \\
\hline TST & 4.4729 & 0.8942 & 0.594 & 0.540 & 1.000 & & & \\
\hline CC & 4.5035 & 1.1476 & 0.625 & 0.629 & 0.452 & 1.000 & & \\
\hline PJ & 4.6157 & 1.4006 & 0.613 & 0.664 & 0.574 & 0.581 & 1.000 & \\
\hline IJ & 4.9338 & 1.4957 & 0.673 & 0.591 & 0.530 & 0.527 & 0.676 & 1.000 \\
\hline
\end{tabular}

Based on the given satisfactory fit indices of the models, hypotheses were tested by examining the estimated structural coefficient. All the proposed hypotheses are fully supported by the results as shown in Table 6 . The path between supply chain procedural justice and trust $(\beta=0.62)$, distributive justice and trust $(\beta=0.68)$, interactional justice and trust $(\beta=0.69)$, trust and affective commitment $(\beta=0.61)$, trust and continuance commitment $(\beta=0.59)$ are found significant and support $\mathrm{H} 1, \mathrm{H} 2, \mathrm{H} 3, \mathrm{H} 4$ and $\mathrm{H} 5$ respectively. 
Tab.6 - Standardized parameter estimates of hypothesized paths. Source: Authors Own

\begin{tabular}{|l|l|l|l|l|l|}
\hline Path & Estimate & Std. Error & R2 & t-value & $\mathrm{p}$-value \\
\hline H1: Procedural justice $=>$ Trust & 0.62 & 0.70 & 0.38 & 10.27 & $\mathrm{p}<0.00$ \\
\hline H2: Distributive justice $=>$ Trust & 0.68 & 0.65 & 0.46 & 12.07 & $\mathrm{p}<0.00$ \\
\hline H3: Interactional justice $=>$ Trust & 0.69 & 0.64 & 0.48 & 12.57 & $\mathrm{p}<0.00$ \\
\hline H4: Trust => Affective commitment & 0.61 & 0.95 & 0.38 & 10.16 & $\mathrm{p}<0.00$ \\
\hline H5: Trust=> Continuance commitment & 0.59 & 0.92 & 0.36 & 9.62 & $\mathrm{p}<0.00$ \\
\hline
\end{tabular}

In fact, trust is essential to developing and maintaining relationships between firms in supply chains (Skandrani et al., 2011). Supply chain justice can mitigate damage trust in varying disruption situations i.e. isolated vs. widespread, short term vs. long duration (Wang et al., 2014). However, the trust has been warranted continuity of the supply chain relationships. While justice has played a critical role to eliminate the unethical behaviors, because unethical behavior negatively effects of continuity of the relationships (Kaynak et al., 2015). Therefore, our study results are supported by the aforementioned studies. In sum, supply chain justice can establish trust in supply chain relationships of the diverse range of the industries especially developing countries. Similarly, supply chain justice also developed both sorts of relationship commitment between partners. In the volatile business environment, justice is vital for supply chain integration and relationship performance.

\section{MANAGERIAL IMPLICATIONS}

The purpose of this study is to understand how supply chain justices i.e. procedural, distributive and interactional improve relationship commitment through developing trust among the supply chain partners. Data collected from 170 manufacturers, distributors, suppliers and retailers of Pakistan. We find that a higher level of justice mutually perceived by all parties is positively associated with a higher level of trust, which is devoted to supply chain activities by all parties. In turn, the higher level of trust contributes to improve affective and continuance commitment of supply chain partners.

The findings of this study provide new insight for the justice and supply chain management literature, and also have some practical implications for managers. First, supply chain justices mutually shared by all supply chain partners can contribute in the development of trust which improves both sorts of relationship commitment significantly. Second, it is important for supply chain manager to create justice atmosphere by incorporating the three dimensions of justice. Third, the results of this study indicate that each of the three justice types contributes to a fair and just atmosphere in the supply chain integration; in such an atmosphere firms will be more likely to develop trust which in turn to ultimately improve affective and continuance commitment of supply chain partners. 


\section{CONCLUSIONS}

We examined the supply chain justices' role in the development of trust and relationship commitment based on the sample of Pakistan supply chain firms. We confirmed that supply chain justices have directly contributed in the development of supply chain partners' trust, which in turn to improve the relationship commitment of supply chain partners.

This study encompasses several limitations which create a new paradigm for further research. First, the study sample units consist of various industries. Therefore, it is the strength of this study, but some industries have very small sample contributions. Second, there is not a differentiation concerning the size of the firms involved in this study. Thus, results may differ for SMEs and large size firms. Third, results reported in this paper from a Pakistan. Therefore, results may differ for firms located in different areas which are operating in different cultural, environmental and political conditions. Therefore, future research might be conducted to examine the justices' impact on trust in the specific industries under different geographic settings.

\section{References}

1. Adams, J. S. (1965). Inequity in social exchange. Advances in Experimental Social Psychology, 2(267-299). http://dx.doi.org/10.1016/S0065-2601(08)60108-2

2. Allen, N. J., \& Meyer, J. P. (1990). The measurement and antecedents of affective, continuance and normative commitment to the organization. Journal of Occupational Psychology, 63(1), 1-18. http://dx.doi.org/10.1111/j.2044-8325.1990.tb00506.x

3. Anderson, E., \& Weitz, B. (1992). The use of pledges to build and sustain commitment in distribution channels. Journal of Marketing Research, 18-34. http://dx.doi.org/10.2307/3172490

4. Bews, N., \& Uys, T. (2002). The impact of organisational restructuring on perceptions of trustworthiness. SA Journal of Industrial Psychology, 28(4). http://dx.doi.org/10.4102/sajip. v28i4.76

5. Bowersox, D. J. (1990). The strategic benefits of logistics alliances (pp. 2-8). Harvard Business Review.

6. Chen, J. V., Yen, D. C., Rajkumar, T. M., \& Tomochko, N. A. (2011). The antecedent factors on trust and commitment in supply chain relationships. Computer Standards \& Interfaces, 33(3), 262-270. http://dx.doi.org/10.1016/j.csi.2010.05.003

7. Cousins, P. D., \& Menguc, B. (2006). The implications of socialization and integration in supply chain management. Journal of Operations Management, 24(5), 604-620. http://dx.doi. org/10.1016/j. jom.2005.09

8. De Ruyter, K., Moorman, L., \& Lemmink, J. (2001). Antecedents of commitment and trust in customer-supplier relationships in high technology markets. Industrial Marketing Management, 30(3), 271-286. http://dx.doi.org/10.1016/S0019-8501(99)00091-7

9. Ellram, L. M., \& Cooper, M. C. (1990). Supply chain management, partnership, and the shipper-third party relationship. The International Journal of Logistics Management, 1(2), 1-10. http://dx.doi.org/10.1108/95740939080001276 
10. Flynn, B. B., Sakakibara, S., Schroeder, R. G., Bates, K. A., \& Flynn, E. J. (1990). Empirical research methods in operations management. Journal of Operations Management, 9(2), 250-284. http://dx.doi.org/10.1016/0272-6963(90)90098-X

11. Flynn, B. B., Zhao, X., Huo, B., \& Yeung, J. H. Y. (2008). We've got the power! How customer power affects supply chain relationships. Business Horizons, 51(3), 169-174. http:// dx.doi.org/10.1016/j.bushor.2008.01.009

12. Greenberg, J. (1990). Employee theft as a reaction to underpayment inequity: The hidden cost of pay cuts. Journal of Applied Psychology, 75(5), 561-568. http://dx.doi.org/10.1037/00219010.75.5.561

13. Greenberg, J., \& Greenberg, J. (1993). The social side of fairness: Interpersonal and informational classes of organizational justice. Justice in the workplace: Approaching fairness in human resource management, Lawrence Erlbaum Associates, Hillsdale, NJ.

14. Griffith, D. A., Harvey, M. G., \& Lusch, R. F. (2006). Social exchange in supply chain relationships: the resulting benefits of procedural and distributive justice. Journal of Operations Management, 24(2), 85-98. http://dx.doi.org/10.1016/j. jom.2005.03.003

15. Hair, J. F., Black, W. C., Babin, B. J., Anderson, R. E., \& Tatham, R. L. (2006). Multivariate data analysis (Vol. 6). Upper Saddle River, NJ: Pearson Prentice Hall.

16. Hair, J. F, Tatham, R. L., Anderson, R. E., \& Black, W. (1998). Multivariate data analysis. (Fifth Ed.) Prentice-Hall: London.

17. Herriot, P., Hirsh, W., Reilly, P., \& Bevan, S. (1998). Trust and transition: Managing today's employment relationship. Chichester, UK: Wiley.

18. Johnston, D. A., McCutcheon, D. M., Stuart, F. I., \& Kerwood, H. (2004). Effects of supplier trust on performance of cooperative supplier relationships. Journal of Operations Management, 22(1), 23-38. http://dx.doi.org/10.1016/j.jom.2003.12.001

19. Kaynak, R., Sert, T., Sert, G., \& Akyuz, B. (2015). Supply chain unethical behaviors and continuity of relationship: Using the PLS approach for testing moderation effects of interorganizational justice. International Journal of Production Economics. http://dx.doi.org /10.1016/ j.ijpe.2015.01.010

20. Kumar, N. (1996). The power of trust in manufacturer-retailer relationships. Harvard Business Review, 74(6), 92.

21. Kumar, N., Scheer, L. K., \& Steenkamp, J. B. E. (1995). The effects of perceived interdependence on dealer attitudes. Journal of Marketing Research (JMR), 32(3) 348-356. http://dx.doi.org/10.2307/3151986

22. Luo, Y. (2007). The independent and interactive roles of procedural, distributive, and interactional justice in strategic alliances. Academy of Management Journal, 50(3), 644-664. http://dx.doi.org/10.5465/AMJ.2007.25526452

23. Moore, K. R. (1998). Trust and relationship commitment in logistics alliances: a buyer perspective. Journal of Supply Chain Management, 34(1), 24-37. http://dx.doi.org/10.1111/ j.1745-493X.1998.tb00039.x

24. Moorman, C., Deshpande, R., \& Zaltman, G. (1993). Factors affecting trust in market research relationships. The Journal of Marketing, 81-101. http://dx.doi.org/10.2307/1252059 
25. Morgan, R. M., \& Hunt, S. D. (1994). The commitment-trust theory of relationship marketing. The Journal of Marketing, 20-38. http://dx.doi.org/10.2307/1252308

26. Narasimhan, R., Narayanan, S., \& Srinivasan, R. (2013). An Investigation of Justice in supply chain relationships and their performance impact. Journal of Operations Management 31(5), 236-247. http://dx.doi.org/10.1016/j.jom.2013.05.001

27. Pillai, R., Williams, E. S., \& Tan, J. J. (2001). Are the scales tipped in favor of procedural or distributive justice? An investigation of the US, India, Germany, and Hong Kong (China). International Journal of Conflict Management, 12(4), 312-332. http://dx.doi.org/10.1108/eb022861

28. Saunders, M. N., \& Thornhill, A. (2003). Organisational justice, trust and the management of change: An exploration. Personnel Review, 32(3), 360-375. http://dx.doi.org/10.1108/00483 480310467660

29. Skandrani, H., Triki, A., \& Baratli, B. (2011). Trust in supply chains, meanings, determinants and demonstrations: A qualitative study in an emerging market context. Qualitative Market Research: An International Journal, 14(4), 391-409. http://dx.doi.org /10.1108/ 13522751111163227

30. Tyler, T. R., \& Lind, E. A. (1992). A relational model of authority in groups. Advances in Experimental Social Psychology, 25, 115-191. http://dx.doi.org/10.1016/S0065-2601(08)60283-X

31. Wang, K. Y., \& Nayir, D. Z. (2009). Procedural justice, participation and power distance: Information sharing in Chinese firms. Management Research Review, 33 (1), 66-78. http:// dx.doi.org/10.1108/01409171011011571

32. Wang, Q., Craighead, C. W., \& Li, J. J. (2014). Justice served: Mitigating damaged trust stemming from supply chain disruptions. Journal of Operations Management, 32(6), 374-386. http://dx.doi.org /10.1016/j.jom.2014.07.001

33. Wang, X., Liao, J., Xia, D., \& Chang, T. (2010). The impact of organizational justice on work performance: Mediating effects of organizational commitment and leader-member exchange. International Journal of Manpower, 31(6), 660-677. http://dx.doi.org/10.1108/014377 21011073364

34. Wilson, D. T., \& Vlosky, R. P. (1998). Interorganizational information system technology and buyer-seller relationships. Journal of Business \& Industrial Marketing, 13(3), 215-234. http://dx.doi.org/10.1108/08858629810222225

35. Wu, W. Y., Chiag, C. Y., Wu, Y. J., \& Tu, H. J. (2004). The influencing factors of commitment and business integration on supply chain management. Industrial Management \& Data Systems, 104(4), 322-333. http://dx.doi.org/10.1108/02635570410530739

36. Yeung, J. H. Y., Selen, W., Zhang, M., \& Huo, B. (2009). The effects of trust and coercive power on supplier integration. International Journal of Production Economics, 120(1), 66-78. http://dx.doi.org/10.1016/j.ijpe.2008.07

37. Zhao, X., Huo, B., Flynn, B. B., \& Yeung, J. H. Y. (2008). The impact of power and relationship commitment on the integration between manufacturers and customers in a supply chain. Journal of Operations Management, 26(3), 368-388. http://dx.doi.org/10.1016/ j.jom.2007.08.002 


\section{Contact information}

Muhammad Ziaullah (Ph. D. Candidate)

Dr. Feng Yi (Associate Professor)

Saleem Abmad (Ph. D. Candidate)

Shumaila Naz. Akhter (Master Candidate)

School of Management and Economics

University of Electronic Science and Technology of China

Qingshuihe Campus: No. 2006, Xiyuan Ave, West Hi-Tech Zone, 611731

Chengdu, Sichuan, P.R. China 


\section{Appendix A-Research Instrument}

Please indicate to what extent you agree/disagree with the following-(circle one number): 1-strongly disagree, 2-moderately disagree, 3-slightly disagree, 4-neutral, 5-slightly agree, 6-moderately agree, 7-strongly agree

\section{Procedural Justice}

1. We are fair in our dealings with this supply chain partner

2. We fully explained the decision-making criteria to this supply chain partner

3. We applied consistent decision-making criteria when dealing with this supply chain partner

\section{Distributive Justice}

1. The supply chain partner contributed a lot to this engagement

2. The supply chain partner received high outcomes or rewards from this engagement

3. We contributed a lot to this engagement

4. We received high outcomes or rewards from this engagement

\section{Interactional Justice}

1. We agree on what is important in this engagement

2. We quickly resolve any disagreement

3. We exchange information in a timely manner

\section{Trust}

1. Even when our partners give us a rather unlikely explanation, we are confident that they are telling the truth.

2. Our partners have often provided us with information that has later proven to be accurate.

3. Our partners usually keep the promises that they make to our firm.

4. Whenever our partners give us advice on our business operations, we know that they are sharing their best judgment.

5. Our organization can count on our partners to be sincere.

6. Though circumstances change, we believe that our partners will be ready and willing to offer us assistance and support.

\section{Relationship Commitment (Affective)}

1. Your supply chain partner feels that if some problems happen in this supply chain, these problems must be made by them

2. Your supply chain partner feels like "part of the family" in this supply chain relationship

3. Your supply chain partner feels "emotionally attached" to this supply chain relationship 
4. This supply chain relationship has a great deal of personal meaning for your supply chain partner

5. Your supply chain partner feels a strong sense of belonging to this supply chain relationship

\section{Relationship Commitment (Continuance)}

1. Your supply chain partner is afraid of what might happen if he leaves this supply chain relationship

2. It would be very hard for your supply chain partner to leave this supply chain relationship right now, even if he wants to

3. It would be too costly for your supply chain partner to leave this supply chain relationship

4. Your supply chain partner staying with this supply chain relationship is a matter of necessity as much as desire 